\section{Bear Spray Safety Program}

A bear spray safety program for the U.S. Geological Survey (USGS) was officially initiated by the Firearms Safety Committee to address accident prevention and to promote personnel training in bear spray and its transportation, storage, and use for defense against wild animals. Bear spray (fig.1) is recognized as an effective tool that can prevent injury in a wild animal attack when used as part of a system including firearms, or used alone for those who choose not to carry a firearm.

The correct tool to use against aggressive bears is not always obvious. Experienced hunters have found that despite using firearms to defend themselves against a charging bear, they were nonetheless attacked and badly hurt. Law enforcement agents for the U.S. Fish and Wildlife Service have experiences that support this reality on the basis of their investigations of encounters between humans and bears since 1992. People who encounter grizzlies and defend themselves with firearms suffer injury about 50 percent of the time. During this same period, persons defending themselves with bear spray escaped injury most of the time, and those who were injured were subjected to attacks of shorter duration and sustained less severe injuries. Canadian bear biologist Dr. Stephen Herrero reached similar conclusions on the basis of his own research, which suggests that a person's chance of incurring serious injury from a charging grizzly bear doubles when bullets are fired rather than when bear spray is used (from U.S. Fish and Wildlife Service, Fact Sheet 8, Living with Grizzlies, Bear Spray vs. Bullets, http://www.fws.gov/mountain-prairie/species/mammals/grizzly/ bear\%20spray.pdf).

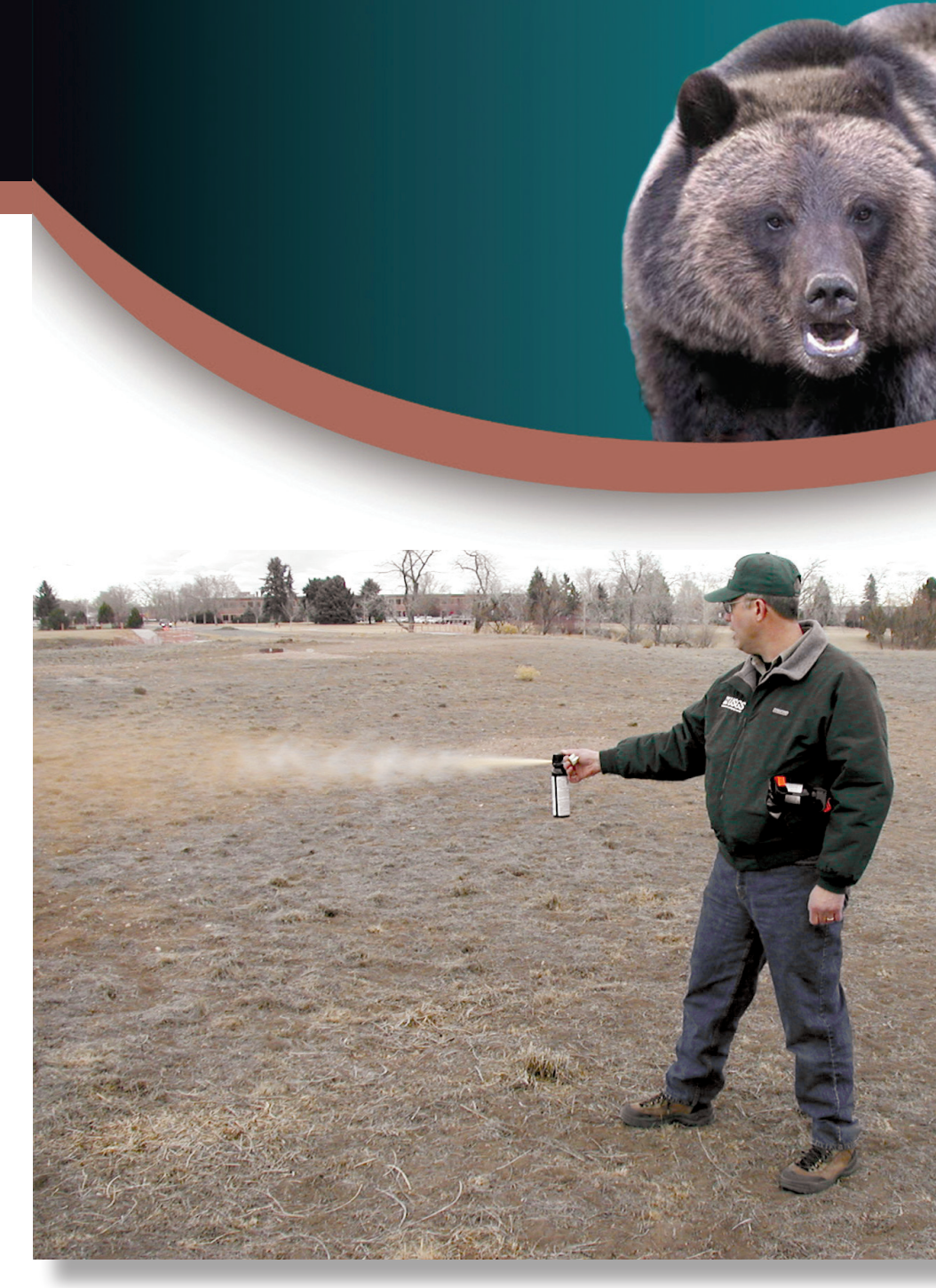

Figure 1. Employee using an active can of bear spray. The active spray travels a greater distance than inert bear spray because of the mass of the pepper oils.

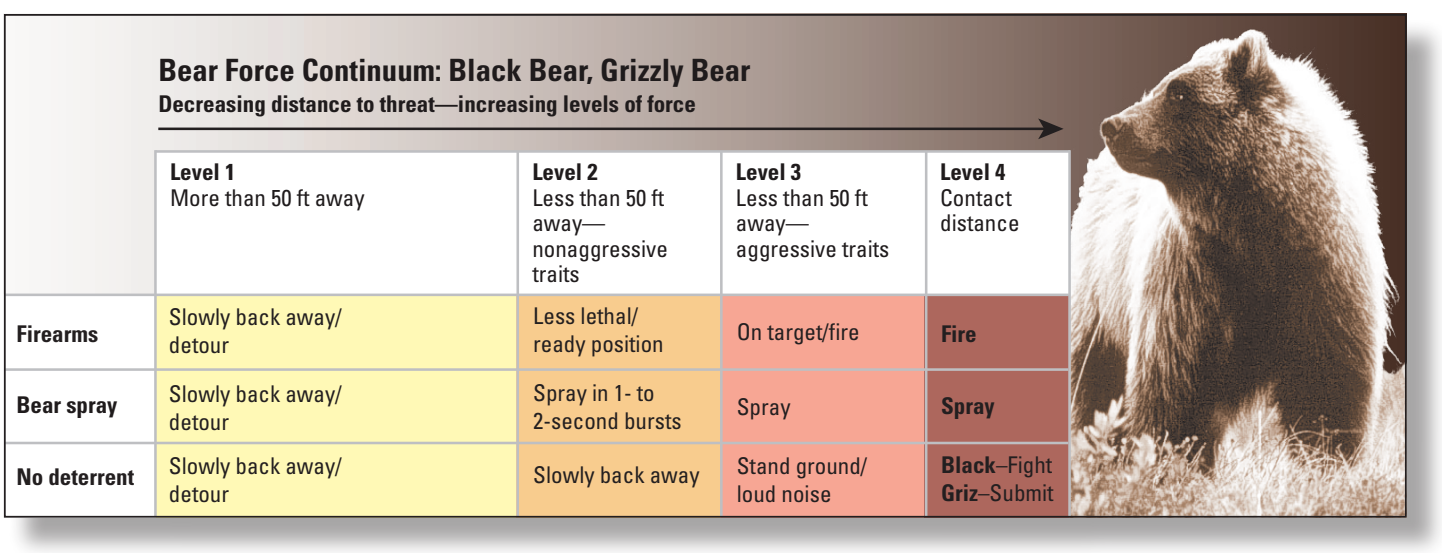

Figure 2. Bear force continuum showing distances to the bear and recommended actions depending on whether the employee has no deterrent, has bear spray, or has a firearm.
The USGS provides firearms safety/proficiency and wild animal behavior training to any employee choosing to carry a firearm in the field as a part of his or her official duties. Awareness of bear behavior is an important element in mitigating potential danger. Estimating distance to the bear and recognizing aggressive and nonaggressive bear behaviors are the best ways of escaping injury (fig. 2). Since the inception of this training, the USGS has had an excellent safety record regarding firearms accidents and incidents involving aggressive bears. Nonetheless, the USGS Firearms Program stresses that the firearm is a tool of last resort and is only to be used when other less-lethal deterrents, such as bear spray, are exhausted or become impractical.

The USGS and U.S. Fish and Wildlife Service support the bear spray recommendations of the Interagency Grizzly Bear Committee (http://www.igbconline.org/html/bearspray.html), which states that bear spray is not a substitute for following proper bear-avoidance safety techniques and that bear spray should be used as a deterrent only when facing an aggressive or attacking bear. 


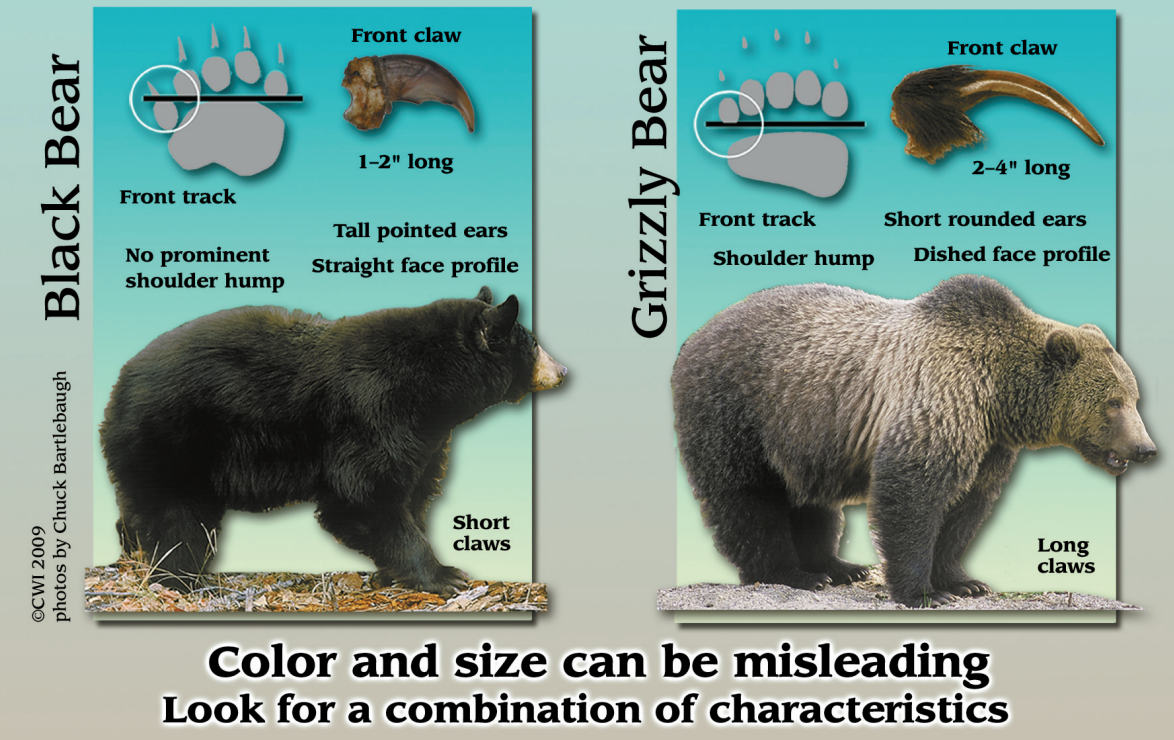
been effective in fending off threatening and attacking bears and preventing injury to the person and animal involved. The proper use of bear spray can reduce the number of bears killed and reduce injuries to people caused by bears (from the Interagency Grizzly Bear Committee at http://www.IGBConline.org).

Although bear spray is a good means of defense, it is not a substitute for vigilance, understanding wild animal characteristics and behavior (fig. 3), and following appropriate avoidance techniques. Never intentionally approach a bear or any wild animal. Do not spray a passive bear to get it to leave the area. Bear spray is only meant to be used on charging or attacking bears (modified from "Be Bear Aware," http://www.centerforwildlifeinformation.org/BeBearAware/BearSpray/bearspray.html).

\section{Obtaining Bear Spray Authorization}

With supervisory permission, any USGS employee or volunteer can be authorized to carry bear spray while on official duty once they have completed the following requirements as specified in chapter 46 of the Occupational Safety and Health Program Requirements Handbook, Safety Manual 445-2-H (http://www.usgs.gov/usgs-manual/handbook/hb/445-2-h/ch46. html):

1. Successful completion of the appropriate Bear Spray Safety Training Course as listed in chapter 46, SM 445-2-H.

2. Completion of a Certificate of Need, including your supervisor's approval, as included in chapter 46, SM 445-2-H, Appendix A.

\section{For Further Information}

Details and cautions (for example, fig. 4) concerning the storage, security, and transport of bear spray also are discussed in chapter 46 of SM 445-2-H.

Bear safety videos are available from the International Association for Bear Research and Management: http://www. bearbiology.com/.

Information on two excellent videos, "Staying Safe in Bear Country" and "Working in Bear Country," is available from the Grizzly Bear Outreach Project at http://www.bearinfo.org/ bearsafety.htm.

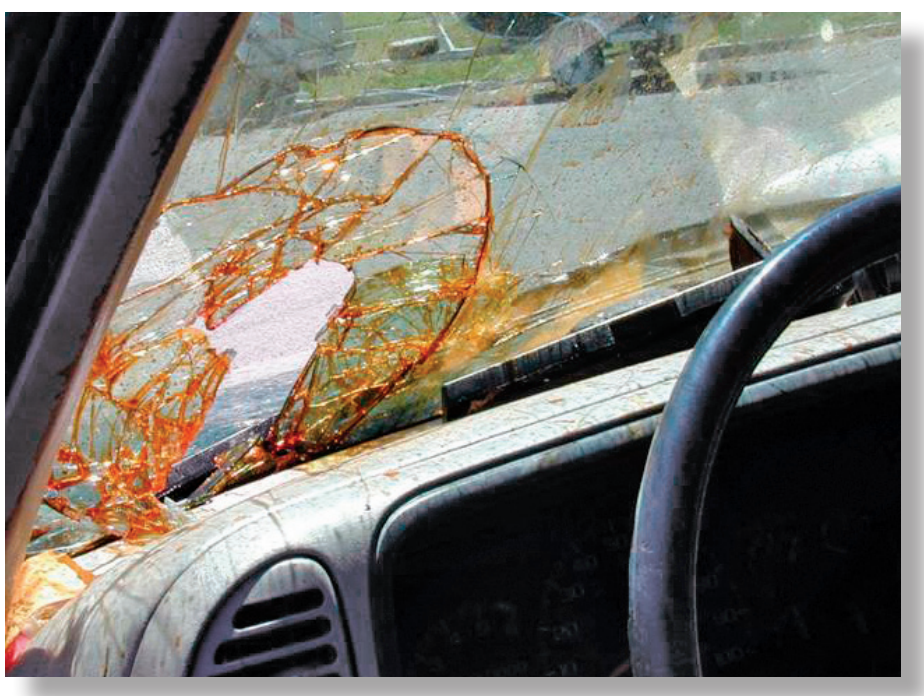

Figure 4. Bear spray canisters can explode as a result of heat buildup if left on the dash of a vehicle, as seen here.

\section{Contacts:}

The USGS Bear Spray Safety Program is overseen by both Bureau and Regional Safety Management. Contact any of the Firearms Safety Managers at the email addresses below:

\section{Bureau}

Eastern Region

Central Region

Western Region Alaska Region
Chad Dickinson

Wayne Martin Ron Kuzniar

John Galloway Chad Smith chad_dickinson@usgs.gov wmartin@usgs.gov rkuzniar@usgs.gov jgallway@usgs.gov cwsmith@usgs.gov
Written By Charles D. Blome and Ronald L. Kuzniar

U.S. Geological Survey, Denver, Colorado

Publishing Support by the Denver Publishing Service Center Edited by Lisa Binder

Layout by Carol Quesenberry 